\title{
Balance Diet Index (BDI) of Under-Five Children During Coronavirus Pandemic
}

\author{
Muhammad Nur Hasan Syah ${ }^{1 *}$ Dian Luthfiana Sufyan ${ }^{1,2,}$ Nurbaya $^{3}$
}

\author{
${ }^{I}$ Nutrition Study Program, Faculty of Health Science, Universitas Pembangunan Nasional Veteran Jakarta, Indonesia \\ ${ }^{2}$ Southeast Asian Ministry of Education Organization Regional Centre for Food and Nutrition (SEAMEO RECFON), University \\ of Indonesia, Indonesia \\ ${ }^{3}$ Nutrition Study Program, Health Polytechnic of Mamuju, West Sulawesi, Indonesia \\ *Corresponding author. Email: mnhasansyah@upnvj.ac.id
}

\begin{abstract}
The Covid-19 pandemic will indirectly have an impact on the ability of families to meet basic needs, including food needs for families with low economic level. Although it has not happened yet, it could resemble the economic crisis that took place two decades ago. From the analysis conducted by WHO and UNICEF, the risk of malnutrition will increase in a crisis-situation. This study aims to determine the intake of food groups among under-five children during Covid-19 pandemic and to assess the possible association of the Balance Diet Index (BDI) with family income. Data were collected using a self-administered Google Form questionnaire. The questionnaire consisted of two sections such as women and under-five children demographic characteristics and Semi Quantitative Food Frequency Questionnaire (SQ-FFQ). The SQ-FFQ was added with pictures of food for portion estimation. Data collection lasted two months from July to August 2020. Data was analyzed using SPSS 25 for univariate, bivariate, and multivariate with confidence interval 95\%. Data found that most parent has a higher education level, both father and mother work as civil servant, policies, or army as well as in the private sector employees. 60,8\% family has higher income. Regarding to portion consumed per day, more than $60 \%$ under-five children have enough portion intake of carbohydrate and animal-protein source, however, more than $70 \%$ has less portion intake of plant-based protein, vegetables, and fruit. The mean of BDI was $38,4 \%$ and there are $59.5 \%$ of under-five children had BDI score lies above the mean. There is no significant association found between BDI categories and respondent characteristics. Multivariate analysis found the odds of having BDI above mean is 1.94 higher on high-income family as compared to low-income family.
\end{abstract}

Keywords: Balance Diet Index (BDI), under-five children, coronavirus, nutrition, pandemic, COVID-19

\section{INTRODUCTION}

Earlier this year the whole nations were alerted by the spread of novel coronavirus, namely Covid-19 caused by SARS-CoV-2 [1]. Wuhan, a small city in China was reported as the ground zero of the virus infection [2]. Not too long after the government of Wuhan locking down outdoor activities, WHO declared the case as Public Health Emergency for International Concern [3]. The individual with Covid-19 showed the main symptoms of common cold such as fever, cough, and shortness of breath. For several folks, Covid-19 was asymptomatic, making it difficult to be detected since the virus was vastly contagious [4].

Indonesia reported the first confirmed cases of Covid-19 in early March 2020. Several weeks later, the central government announced the policy of large-scale social distancing (PSBB) for controlling the spread of Covid-19 by restricting any form of outdoor social activities such as working, praying, and schooling [5]. Constraint on those activities become conducted at home, was shocked for some folks who gain their income from informal sector jobs such as driver, street vendor, labor, and whatsoever. This unanticipated policy affected the food expenses of a family and put them to vulnerable groups of food insecurity that can lead to malnutrition [6-8]. If so, under-five children will be the most affected, since they still grow. Definitely, as SDGs mentioned that the Covid-19 pandemic added a threat to food systems besides climate shocks, conflict, and locust crisis [9]. Previously, the proportion of stunting in Indonesia was $30.7 \%$ and estimated to be affected since UNICEF noted food insecurity will be the sting in the tail of Covid-19 [10,11]. This study aims to determine the intake of food groups among under-five children during the Covid-19 pandemic and to assess possible association of the Balance Diet Index (BDI) with family income. To the best of the authors' knowledge, there are no other studies investigating underfive children BDI during the Covid-19 pandemic in Indonesia.

\section{METHODS}

\subsubsection{Study setting}

Java and Sulawesi were purposively selected since the site implemented large-scale social distancing (PSBB) during 
the pandemic. PSBB was a method of movement restriction applied by several local governments of Indonesia with high confirmed cases to reduce the spread of coronavirus. Both areas reflected different characteristics in terms of geographical conditions. Java is urban while Sulawesi is more rural area.

\subsubsection{Study participants and recruitment}

The subjects were married women aged 19 to 49 years old who have under-five children, own and able to operate a smartphone with in internet connection. The recruitment of the participants was conducted online using a link of Google Form that is shared through Whatsapp and Social Media (Instagram and Facebook). A total of 74 women participated in this study.

\subsubsection{Balance Diet Index}

Balance Diet Index (BDI) was developed by using the BDI3-60 system, meaning that the index with 3 levels of the scoring system, and consisting of 6 components and 0 aspects related to non-communicable disease [12]. The score was derived from 6 food groups, such as carbohydrate, animal protein, plant protein, vegetable, fruit, and milk that were scored based on the actual portion consumption of the children.

\subsubsection{Ethical Consideration}

The research proposal was fully approved by the Health Research Ethics Committee of the Universitas Pembangunan Nasional Veteran Jakarta (approval number 2617/VI/2020/KEPK). Informed consent was obtained from each participant prior data collection.

\subsubsection{Data Collection}

Data were collected using a self-administered Google Form questionnaire. The questionnaire consisted of two sections such as women and under-five children demographic characteristics and Semi Quantitative Food Frequency Questionnaire (SQ-FFQ). The food list for SQ-FFQ questionnaire was obtained from all food groups from a food photography book that was mainly consumed by children. The SQ-FFQ was added with pictures of food for portion estimation. Data collection lasted two months from July to August 2020.

\subsubsection{Data Analysis}

Data were analyzed using SPSS 25 for univariate, bivariate, and multivariate with confidence interval $95 \%$. Univariate analysis was done to present women and under-five children characteristics and food portion consumed during the pandemic. All characteristics variables were reported using frequencies and percentages. Bivariate analysis was conducted using chi-square to identify any potential association between covariates and children's food consumption. Further, multivariate analysis was performed using logistics regression to assess crude and adjusted odd ratio. Variables that show significant values less than 0,05 are treated as covariates on the analysis.

\section{RESULTS}

In our analysis, out of 71 under-five children, 52 children have adequate portion of carbohydrate intake, 48 children who have adequate portion of animal protein, 22 children with adequate portion of plant protein, 31 children with adequate portion of vegetable intake and only 17 children have adequate portion of fruit intake (Table 2). Table 1 shows the children's family characteristics, most of the mother was aged 19-29 years old, live in nuclear family, both parents were higher education graduates, and earn high income for the family. Most mothers occupied informal sector jobs such as civil servants, while the father mostly were private employees.

We found the mean of the BDI score was 34.8 , and there are $59.5 \%$ of under-five children had BDI score lies above the mean. Table 4 showed cross-tabulation between BDI and respondent characteristics. There is no significant association found between BDI categories and respondent characteristics. However, mother education and income variable showed $\mathrm{P}<0.25$, so that we proceed to logistics regression by treating them as predictors (Table 5). In the first step of the multivariate analysis, we put both variables on the model and found no significant association between BDI and mother education nor income. In the second step, we proceeded the analysis by taking predictors with the smallest significance level and put it into the model. The second model found the odds of having BDI above mean is 1.94 higher on high-income family as compared to low income-family

\section{DISCUSSION}

Malnutrition is a reality faced by millions of children in developing countries even before the pandemic. The Covid19 pandemic will indirectly have an impact on the ability of families to meet basic needs, including food needs for families with low economic level. And experts predict that COVID-19 will affect children far beyond those its impact on health directly.[13]

Indonesia implements some prevention actions such as physical distancing and social restrictions to reduce the risk of Covid-19 transmission. Public places such as schools, offices, markets, and restaurants, etc. have been closed or given had limited working hours during this pandemic time. This social restriction policy turned out to have a significant impact on the socio-economic life of the community. This pandemic has disrupted the economic system up to the 
household level. It causes household income reduction and also lowers the purchasing power.[14]

Although it has not happened yet, it could resemble the economic crisis that took place two decades ago. From the analysis conducted by WHO and UNICEF, the risk of malnutrition will increase in a crisis-situation.

This study found that consumption of children during a pandemic adjusted the daily portion needs based on balanced nutrition guidelines. $60-70 \%$ of children under five reach a daily portion of carbohydrates, animal protein, and milk. However, only $20-40 \%$ of the consumption of plant-based protein, vegetables and fruit adjust the daily portion. This data was not different before the pandemic, more than $90 \%$ of the population does not consume enough vegetables, and fruits. [15] The results are also in line with several studies where the consumption of staple foods and protein mostly meets the daily portion, as well as portions for vegetables and fruit. During the pandemic, most families in Indonesia still had sufficient income so that they could still meet their daily nutritional needs. Apart from this, the pandemic has increased the consumption of vegetables and fruit as a source of vitamins and minerals to support endurance. The changes in dietary patterns during the COVID-19 could also be driven by the fear and anxiety many people around the globe are experiencing. The evidences showed that the change of dietary habits could also be affected by conditions of emotional disturbance such as stress and distress whereby increasing distress levels are associated with unhealthy dietary patterns and lower quality of the diet.[16]

Table 1 Respondent's characteristics
BDI was used to ensure that children's consumption according to the principles of balanced nutrition. Although some food groups were unable to meet daily portions, most children had BDI scores above the mean. Research related to BDI was limited, several studies said that BDI was a part of consuming various foods. Therefore, BDI also deals with access to food, economy, and behavior including knowledge and attitudes. In this study, there was no significant relationship between BDI and characteristics, but more than $50 \%$ of children with good BDI were also in good characteristics, such as parents' income and education. $[12,17,18]$

During the pandemic, families can provide children's food with good quality, although there are still some families had low quality. From the analysis, families with high income have better opportunities in BDI. Therefore, despite the pandemic, the family still has a good income. With an unpredictable pandemic, changes in family income may occur and can affect the quality of a child's diet. Recent research shows that families with good economic status tend to have unhealthy diets during a pandemic. [19]

\begin{tabular}{|l|c|c|}
\hline \multicolumn{1}{|c|}{ Characteristics } & $\mathbf{n = 7 4}$ & \% \\
\hline Mother Age group & 40 & 54.1 \\
$19-29$ & 34 & 45.9 \\
$30-49$ & & \\
& 48 & 64.9 \\
\hline Family type & 26 & 35.1 \\
Nuclear & & \\
Extended & 68 & 91.9 \\
\hline Mother Education & 6 & 8.1 \\
Higher Education & & \\
Low-Middle Education & 59 & 79.7 \\
\hline Father Education & 15 & 20.3 \\
Higher Education & & \\
Low-Middle Education & 33 & 44.6 \\
& 15 & 20.3 \\
Mother Occupation & 6 & 8.1 \\
Civil servant/Police/Army & 20 & 27 \\
Private Employees & & 33.8 \\
Entrepreneur & 25 & 39.2 \\
Not Work/Housewife & 29 & 22.9 \\
\hline Father Occupation & 17 & 4.1 \\
Civil servant/Police/Army & 3 & \\
Private Employees & & \\
Entrepreneur & & \\
Not Work/Housewife & & \\
& & \\
\hline
\end{tabular}




\begin{tabular}{|l|l|l|}
\hline Monthly Income (total) & 29 & 39.2 \\
Low - middle & 45 & 60.8 \\
High & & \\
\hline
\end{tabular}

Table 2 Description on food intake among under-five children during large-scale social distancing

\begin{tabular}{|l|c|c|}
\hline Nutrient Intake (portion/day) & $\mathbf{n = 7 4}$ & \% \\
\hline $\begin{array}{l}\text { Carbohydrate Sources } \\
<3\end{array}$ & 22 & 29.7 \\
$\geq 3$ & 52 & 70.3 \\
& & \\
\hline Animal-base Protein Sources & 26 & 35.1 \\
$\quad<2$ & 48 & 64.9 \\
$\geq 2$ & 52 & 70.3 \\
\hline Plant-base Protein Sources & 22 & 29.7 \\
$<2$ & & \\
$\geq 2$ & 43 & 58.1 \\
\hline Vegetables & 31 & 41.9 \\
$<2$ & & \\
$\geq 2$ & 57 & 77.0 \\
\hline Fruits & 17 & 23.0 \\
$<3$ & 16 & 21.6 \\
$\geq 3$ & 58 & 78.4 \\
\hline Milk & & \\
$<1$ & & \\
$\geq 1$ & & \\
\hline
\end{tabular}

Table 3 Description on Balance Diet Index (BDI) category among under-five children during large-scale social distancing

\begin{tabular}{|l|c|c|}
\hline Balance Diet Index (BDI) & $\mathbf{n = 7 4}$ & $\%$ \\
\hline Category score & 30 & 40.5 \\
$<$ mean & 44 & 59.5 \\
$\geq$ mean & & \\
\hline
\end{tabular}

Table 4 Relationship between Demographic with Gizi Seimbang Index (IGS) category among under-five children during large-scale social distancing

\begin{tabular}{|c|c|c|c|c|c|}
\hline \multirow[t]{3}{*}{ Demographic } & \multicolumn{4}{|c|}{ Gizi Seimbang Index (IGS) category } & \multirow[t]{3}{*}{$\mathbf{p}$} \\
\hline & \multicolumn{2}{|c|}{$<$ mean } & \multicolumn{2}{|c|}{$\geq$ mean } & \\
\hline & $\mathbf{n}$ & $\%$ & $\mathbf{n}$ & $\%$ & \\
\hline Type of residence & & & & & \\
\hline Rural & 16 & 41.0 & 23 & 59.0 & 0.929 \\
\hline Urban & 14 & 40.0 & 21 & 60.0 & \\
\hline Family type & & & & & \\
\hline Nuclear & 19 & 39.6 & 29 & 60.4 & 0.820 \\
\hline Extended & 11 & 42,3 & 15 & 57.7 & \\
\hline Mother Education & & & & & \\
\hline Higher Education & 29 & 42.6 & 39 & 57.4 & 0.214 \\
\hline Low-Middle Education & 1 & 16.7 & 5 & 83.3 & \\
\hline Father Education & & & & & \\
\hline Higher Education & 25 & 42.4 & 34 & 57.6 & 0.524 \\
\hline Low-Middle Education & 5 & 33.3 & 10 & 66.7 & \\
\hline Monthly income (total) & & & & & \\
\hline
\end{tabular}




\begin{tabular}{|c|c|c|c|c|c|}
\hline $\begin{array}{l}\text { Low - middle } \\
\text { High }\end{array}$ & $\begin{array}{c}9 \\
21\end{array}$ & $\begin{array}{l}31.0 \\
46.7\end{array}$ & $\begin{array}{l}20 \\
24\end{array}$ & $\begin{array}{l}69.0 \\
53.3\end{array}$ & 0.181 \\
\hline Total & 29 & 39.2 & 45 & 60.8 & \\
\hline
\end{tabular}

Table 5 Multivariate analysis logistic regression

\begin{tabular}{|l|l|c|c|c|}
\hline & \multicolumn{1}{|c|}{ Variable } & Coefficient & P & OR (95\% CI) \\
\hline Step 1 & Mother Education & 1.063 & 0.355 & $2.90(0.30-27.61)$ \\
\hline & Monthly income (total) & 0.537 & 0.298 & $1,71(0.62-4.70)$ \\
\hline & Constant & 0.112 & 0.708 & 1.12 \\
\hline Step 2 & Monthly income (total) & 0.665 & 0.184 & $1.94(0.73-5.19)$ \\
\hline & Constant & 0.134 & 0.655 & 1.14 \\
\hline
\end{tabular}

\section{CONCLUSION}

Pandemic conditions do not affect changes in the child's diet. Most of the children had above average BDI scores. It can happen because most families still have high incomes.

\section{ACKNOWLEDGMENT}

Authors would like to thank Universitas Pembangunan Nasional Veteran Jakarta and Health Polytechnic Mamuju for their support. No external funds supported this work.

\section{REFERENCES}

[1] WHO. Novel Coronavirus (2019-nCoV) Situation Report - 10. WHO Bulletin. Geneva, Switzerland: World Health Organization; 2020. p. 1-7.

[2] WHO. Coronavirus Disease 2019 (COVID-19) Situation Report-94. Vol. 14, WHO Bulletin. Geneva, Switzerland: World Health Organization; 2020. p. e01218.

[3] WHO. COVID 19 Public Health Emergency of International Concern (PHEIC). Geneva, Switzerland: WHO; 2020.

[4] Sheikhi K, Shirzadfar H, Sheikhi M. A Review on Novel Coronavirus (Covid-19): Symptoms , Transmission and Diagnosis Tests Research in Infectious Diseases and Tropical Medicine A Review on Novel Coronavirus ( Covid-19 ): Symptoms, Transmission and Diagnosis Tests. Res Infect Dis Trop Med. 2020;2(1):1-8.

[5] Tosepu R, Effendy DS, Ahmad LOAI. The first confirmed cases of Covid-19 in Indonesia Citizens. Public Heal Indones. 2020;6(2):70-1.
K, Feikin DR, et al. Nutritional status of underfive children living in an informal urban settlement in Nairobi, Kenya. J Heal Popul Nutr. 2011;29(4):357-63.

[7] Mulu E, Mengistie B. Household food insecurity and its association with nutritional status of under five children in Sekela District, Western Ethiopia: A comparative cross-sectional study. BMC Nutr. 2017;3(1).

[8] Singh A, Singh A, Ram F. Household food insecurity and nutritional status of children and women in Nepal. Food Nutr Bull. 2014;35(1):311.

[9] Galanakis CM. The Food Systems in the Era of the Coronavirus (COVID-19) Pandemic Crisis. Foods. 2020;9(523):445-72.

[10] Kementerian Kesehatan RI. Riset Kesehatan Dasar (Riskesdas) 2018. Jakarta; 2018.

[11] The Lancet Global Health. Food insecurity will be the sting in the tail of COVID-19. Lancet Glob Heal. 2020;8(6):e737.

[12] Hardiansyah A, Hardinsyah, Sukandar D. Alternative indices for the assessment of nutritional quality of balanced diet of Indonesian children 4-6 years old. Pakistan J Nutr. 2015;14(10):716-20.

[13] Sly L. Hunger could be more deadly than coronavirus in poorer countries. The Washingtong Post. 2020.

[14] FAO. Impact of COVID-19 on food security and nutrition (FSN). United Nations. 2020. p. 1-8.

[15] MoH. Laporan Nasional Riset Kesehatan Dasar (Riskesdas) tahun 2018. Jakarta, Indonesia; 2019.

[16] Naja F, Hamadeh R. Nutrition amid the COVID19 pandemic: a multi-level framework for action. Eur J Clin Nutr. 2020;

[17] Wahyuningsih U, Anwar F, Kutiyah L. KUALITAS KONSUMSI PANGAN KAITANNYA DENGAN STATUS GIZI ANAK USIA 2-5 TAHUN PADA MASYARAKAT ADAT KASEPUHAN CIPTAGELAR DAN SINAR RESMI. Indones J Heal Dev. 2020;2(1). [18] Danty FR, Syah MNH, Sari AE. Hubungan Indeks Gizi Seimbang Dengan Status Gizi Pada Remaja 
Putri Di SMK Kota Bekasi. J Kesehat Indones.

2019;10(1):43-54.

[19] Górnicka M, Drywień ME, Zielinska MA,

Hamułka J. Dietary and lifestyle changes during COVID-19 and the subsequent lockdowns among

Polish adults: A Cross-sectional online survey

PLifeCOVID-19 study. Nutrients.

2020;12(8):2324. 